\title{
A point mutation in the iron-responsive element of the L-ferritin gene in a family with hereditary hyperferritinemia cataract syndrome
}

\author{
Karen Wong $\mathrm{MD}^{1}$, Yousef Barbin², Subrata Chakrabarti MD², Paul Adams MD ${ }^{3}$
}

\begin{abstract}
K Wong, Y Barbin, S Chakrabarti, P Adams. A point mutation in the iron-responsive element of the L-ferritin gene in a family with hereditary hyperferritinemia cataract syndrome. Can J Gastroenterol 2005;19(4):253-255.
\end{abstract}

BACKGROUND: Hereditary hyperferritinemia cataract syndrome is an autosomal dominant condition that is characterized by a high serum ferritin level and bilateral early-onset cataracts in the absence of iron overload. The genetic abnormality is identified as a mutation in the $5^{\prime}$ regulatory region of the L-ferritin messenger RNA known as the iron-responsive element (IRE). The IRE controls ferritin synthesis in response to cytoplasmic iron pools by interacting with regulatory proteins called iron responsive proteins. Mutations in the IRE decrease its affinity for iron responsive proteins, leading to the constitutive synthesis of L-ferritin which results in hyperferritinemia and the intracellular accumulation of ferritin in the lens and eventual cataract formation.

PATIENTS AND METHODS: A 22-year-old woman who was being investigated for hyperferritinemia was diagnosed with hereditary hyperferritinemia cataract syndrome after an extensive workup, including genetic testing for hemochromatosis and a liver biopsy to rule out iron overload. She developed anemia with phlebotomy treatments and subsequently developed symptomatic cataracts. The pedigree of her family affected with cataracts was consistent with an autosomal dominant transmission pattern.

DNA was extracted from peripheral leukocytes of eight family members, four of whom were affected by cataracts. Polymerase chain reaction amplification of the $5^{\prime}$ region of the L-ferritin gene was performed and a heterozygous point mutation $(\mathrm{G} 32 \mathrm{~T})$ was identified in the bulge region of the IRE.

CONCLUSION: The combination of early-onset cataracts and an elevated ferritin level should suggest this genetic syndrome.

Key Words: Cataracts; Hyperferritinemia; Iron-responsive element; L-ferritin

$\mathrm{H}$ ereditary hyperferritinemia cataract syndrome (HHCS) is an autosomal dominant disorder that was first described in 1995 independently by Bonneau et al (1) and Girelli et al (2). It is characterized by early-onset bilateral cataracts and high serum ferritin levels in the absence of iron overload. Iron studies are otherwise normal, with normal to low serum iron and transferrin saturation (3). Because of the assumption of iron overload, these patients are often mistakenly treated with repeat phlebotomies, resulting in iron deficiency anemia. The cataracts in this syndrome have a distinct morphology typified

\section{Une mutation ponctuelle de l'élément réactif} au fer du gène $L$-ferritine au sein d'une famille atteinte du syndrome héréditaire cataractehyperferritinémie

\begin{abstract}
HISTORIQUE : Le syndrome héréditaire cataracte-hyperferritinémie est un trouble autosomique dominant caractérisé par un taux de ferritine sérique élevé et des cataractes bilatérales à apparition précoce en l'absence de surcharge ferrique. L'anomalie génétique est repérée par une mutation de la zone de régulation $5^{\prime}$ de l'ADN messager L-ferritine, appelée élément réactif au fer (ÉRF). L'ÉRF contrôle la synthèse de la ferritine en réponse à un capital ferrique cytoplasmique par une interaction avec des protéines de régulation, les protéines réactives au fer. Les mutations de l'ÉRF réduisent son affinité avec les protéines réactives au fer, entraînant la synthèse constitutive de la $\mathrm{L}$-ferritine, ce qui provoque une hyperferritinémie, l'accumulation intracellulaire de ferritine dans les cristallins et la formation éventuelle de cataractes.

PATIENTS ET MÉTHODOLOGIE : Une femme de 22 ans ayant subi des examens pour déceler l'hyperferritinémie a obtenu un diagnostic de syndrome héréditaire de cataracte-hyperferritinémie après un bilan approfondi, y compris des tests génétiques d'hémochromatose et une biopsie hépatique pour écarter la possibilité de surcharge ferrique. Elle s'est mise à faire de l'anémie avec des traitements contre une phlébotomie et a ensuite présenté des cataractes symptomatiques. La généalogie des membres de la famille atteints de cataractes confirmait un schème de transmission autosomique dominante.

L'ADN a été extrait des leucocytes périphériques de huit membres de la famille, dont quatre souffraient de cataractes. L'amplification de la réaction en chaîne de la polymérase de la zone $5^{\prime}$ du gène L-ferritine a été exécutée, et une mutation ponctuelle hétérozygote $(\mathrm{G} 32 \mathrm{~T})$ a été repérée dans la zone bombée de l'ÉRF.

CONCLUSION : L'association de cataractes à apparition précoce et d'un taux de ferritine élevé devrait laisser supposer la présence d'un syndrome génétique.
\end{abstract}

by slowly progressive cystic flecks with crystalline deposits in the lens cortex and nucleus that may be pathognomonic for HHCS (4). The prevalence of this syndrome is not known, but a research group in Australia estimated that there is a prevalence of at least one in 200,000 in southeastern Australia (4). Mutations in the iron-responsive element (IRE) of the L-ferritin gene located on chromosome 19q13.33-13.4 is the molecular basis of this genetic disorder. The IRE is a stem-loop structure located in the $5^{\prime}$ noncoding region of the L-ferritin messenger RNA (mRNA). The role of the IRE is to interact with the

\footnotetext{
${ }^{1}$ Department of Medicine; ${ }^{2}$ Department of Pathology; ${ }^{3}$ Department of Medicine, Division of Gastroenterology, University of Western Ontario, London, Ontario

Correspondence: Dr Paul Adams, Department of Medicine, London Health Sciences Centre, University Campus,

339 Windermere Road, PO Box 5339, London, Ontario N6A 5A5. Telephone 519-858-5125, fax 519-858-5114, e-mail padams@uwo.ca Received for publication August 17, 2004. Accepted January 19, 2005
} 


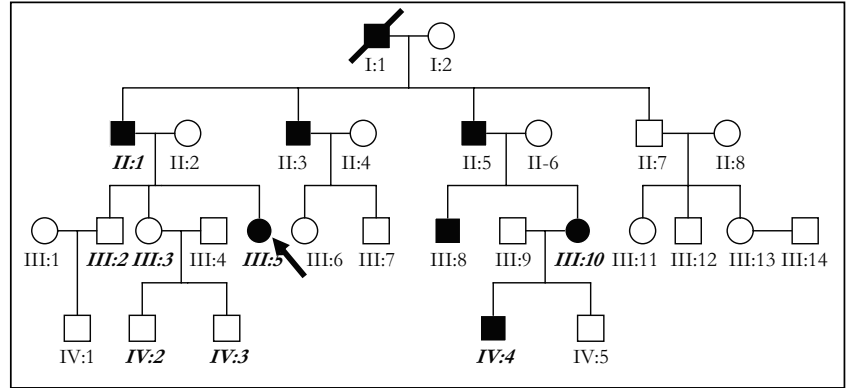

Figure 1) Pedigree of family with hereditary hyperferritinemia cataract syndrome. The eight individuals in this study were: II:1, III:2, III:3, III:5, III:10, IV:2, IV:3, IV:4. Solid shapes: individuals with cataracts; squares: men; circles: women; slash: deceased; arrow: proband

cytoplasmic iron-responsive proteins (IRP) to regulate ferritin synthesis in response to cytoplasmic iron pools. When iron pools are adequate, the binding of the IRP to the IRE prevents the recruitment of the small ribosomal subunit to the mRNA, thereby, inhibiting the initiation of translation (5). The IRE is not unique to $\mathrm{L}$-ferritin but is also found in $\mathrm{H}$-ferritin, the $3^{\prime}$ region of the transferrin receptor mRNA (6) and the erythroid aminolevulinate synthase mRNA (7). Mutations in the IRE have been shown to decrease its affinity for the IRP, leading to the unregulated, constitutive synthesis of the L-ferritin mRNA, irrespective of the body's iron status. This change in affinity has been demonstrated in vivo with lymphoblastoid cell lines (8) and in vitro using thermodynamic analysis (9). Ferritin is normally expressed in the lens and is thought to function as an antioxidant (4). It is the overproduction of L-ferritin resulting in intracellular accumulation in the lens that is thought to lead to the formation of cataracts in HHCS (4).

Almost 20 different mutations have been described in the IRE of the L-ferritin gene. Heterozygous point mutations in the $5^{\prime}$ region of the L-ferritin gene account for the majority of the mutations with the exception of three deletion mutations (from two-base pair to 28-base pair deletions). We set out to determine whether the family in the present study had a mutation in the IRE.

\section{CASE PRESENTATION}

The proband (III-5) (Figure 1) was a 22-year-old woman who was initially found to have an elevated ferritin level of $1296 \mu \mathrm{g} / \mathrm{L}$ on bloodwork drawn during an episode of infectious mononucleosis at 16 years of age. She was referred to the hepatology clinic for further assessment of this persistent elevated ferritin. Aside from hyperferritinemia, her iron studies were otherwise normal. Her serum iron was $35.6 \mu \mathrm{g} / \mathrm{mL}$ and transferrin saturation was $45 \%$. Workup included genetic testing for hemochromatosis which was negative for both the C282Y and H63D mutations of the hemochromatosis gene. A liver biopsy did not show evidence of iron overload with no stainable iron and a normal liver iron concentration of $5.4 \mu \mathrm{mol} / \mathrm{g}$ (normal $0 \mu \mathrm{mol} / \mathrm{g}$ to $35 \mu \mathrm{mol} / \mathrm{g}$ dry weight). For six years, she was noted to have a serum ferritin greater than $1000 \mu \mathrm{g} / \mathrm{L}$. At 22 years of age, the patient underwent weekly $500 \mathrm{~mL}$ phlebotomy treatments and dropped her hemoglobin level from $153 \mathrm{~g} / \mathrm{L}$ to $84 \mathrm{~g} / \mathrm{L}$ over one month. She subsequently developed symptomatic cataracts and, given a positive family history of cataracts, the diagnosis of HHCS was made and she underwent surgical treatment.

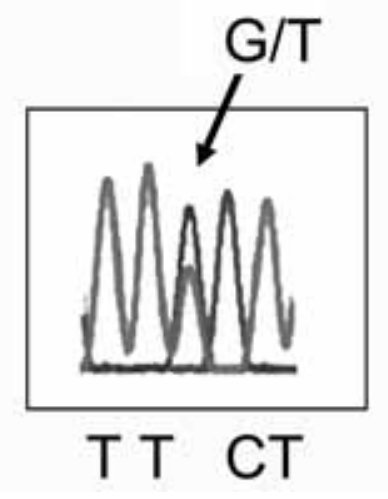

Figure 2) Genetic mutation G32T in the L-ferritin gene in an affected individual

\section{DNA analysis}

\section{METHODS}

Genomic DNA was extracted from peripheral blood leukocytes of eight individuals in the pedigree (Figure 1), four of whom were affected by cataracts. The $5^{\prime}$ region of the L-ferritin gene was amplified by polymerase chain reaction (PCR) using flanking primers (forward 5'-TCCTTGCCACCGCAGATTG-3'; reverse 5'-TTGGCAAGAAGGAGCTAACC-3') (10). PCR reactions were made up to a total volume of $50 \mu \mathrm{L}$ containing $25 \mathrm{pmol}$ of each primer, $1 \mathrm{U}$ Taq polymerase and $2.5 \mu \mathrm{mol}$ magnesium chloride. PCR reactions were carried out under the following conditions using the PTC- 100 Thermocycler: denaturation at $94^{\circ} \mathrm{C}$ for $30 \mathrm{~s}$, annealing at $54^{\circ} \mathrm{C}$ for $30 \mathrm{~s}$ and extension at $72^{\circ} \mathrm{C}$ for $90 \mathrm{~s}$. Nested PCR was performed using the same primers to yield a 287-base pair product. PCR products were gel purified and DNA extracted using QIAquick Gel Extraction Kit (QIAGEN Inc, Canada). DNA was sent for direct sequencing at the Robarts Research Institute (London, Ontario) sequencing laboratory.

\section{RESULTS}

Serum ferritin levels in affected individuals were elevated and ranged from $1307 \mu \mathrm{g} / \mathrm{L}$ to $1976 \mu \mathrm{g} / \mathrm{L}$. The ferritin levels in the unaffected individuals ranged from $17 \mu \mathrm{g} / \mathrm{L}$ to $20 \mu \mathrm{g} / \mathrm{L}$. Sequencing showed a heterozygous point mutation at position $+32(G \rightarrow T)$ in the affected members (Figure 2$)$. This mutation was located in the bulge of the IRE.

\section{DISCUSSION}

During the workup of an individual for hyperferritinemia, a family was identified with a clinical suspicion of HHCS. The affected individuals of this family were found to have high serum ferritin levels (1307 $\mu \mathrm{g} / \mathrm{L}$ to $1976 \mu \mathrm{g} / \mathrm{L})$ and early-onset cataracts requiring surgical intervention. DNA analysis identified a heterozygous mutation (G32T) in the bulge of the IRE in the affected members. This mutation has also been described in six individuals in France $(11,12)$ and one family in Australia (4). The G32T mutation has previously been shown to lead to a decrease in binding affinity of IRE to the IRP by in vitro gel retardation assays performed by Martin et al (12). Mutations in the bulge of the IRE are the most common and account for approximately $50 \%$ of all mutations described in the IRE (11).

There is a spectrum in the clinical presentation of HHCS varying from mildly elevated ferritin levels and asymptomatic 
cataracts, to ferritin levels greater than $1000 \mu \mathrm{g} / \mathrm{L}$ and cataracts requiring surgical intervention in childhood. There have been suggestions that each unique mutation may correspond to the severity of HHCS and that varying degrees of the effect on binding affinity may explain this phenotypic variability. This variation of binding affinity was demonstrated by Allerson et al (9) using thermodynamic analysis. Although there appears to be a correlation between each mutation and disease severity, the range of ferritin levels in individuals with the same mutation is wide and the age of onset of cataracts varies among families with the same mutation as well as among members of the same family. This suggests that there may be other determinants, such as environmental factors, that affect the penetrance of this genetic disorder or alter the phenotypic manifestation (13). Wide ranges in ferritin levels may or may not reflect coexisting inflammatory conditions. In the present study, the patient developed symptoms of cataracts in her

\section{REFERENCES}

1. Bonneau D, Winter-Fuseau I, Loiseau MN, et al. Bilateral cataract and high serum ferritin: A new dominant genetic disorder? J Med Genet 1995;32:778-9.

2. Girelli D, Olivieri O, De Franceschi L, Corrocher R, Bergamaschi G, Cazzola M. A linkage between hereditary hyperferritinemia not related to iron overload and autosomal dominant congenital cataract. Br J Haematol 1995;90:931-4.

3. Beaumont C, Girelli D. Hereditary hyperferritinemia-cataract syndrome. In: Templeton DM, ed. Molecular and Cellular Iron Transfer. Basel, Switzerland: Marcel Dekker, 2002:761-74.

4. Craig JE, Clark JB, McLeod JL, et al. Hereditary hyperferritinemiacataract syndrome, prevalence, lens morphology, spectrum of mutations, and clinical presentations. Arch Ophthalmol 2003;121:1753-61.

5. Muckenthaler M, Gray NK, Hentze MW. IRP-1 binding to ferritin mRNA prevents the recruitment of the small ribosomal subunit by the cap-binding complex eIF4F. Mol Cell 1998;2:383-8.

6. Casey JL, Koeller DM, Ramin VC, Klausner RD, Harford JB. Iron regulation of transferrin receptor mRNA levels requires ironresponsive elements and a rapid turnover determinant in the 3' untranslated region of the mRNA. EMBO J 1989;8:3693-9.

7. Theil EC. Iron regulatory elements (IREs): A family of mRNA non-coding sequences. Biochem J 1994;304:1-11. early 20s; however, individual IV:4, who was six years of age, was already known to have cataracts on ophthalmological examination.

Timely diagnosis of this disorder has been challenging because of the low awareness of this condition among physicians. HHCS should be added to the differential for hyperferritinemia; in particular, in the absence of iron overload. However, the finding of high ferritin levels is often incidental because testing is not routine in ophthalmology practice. Although Craig et al (4) have described the distinct morphology of these cataracts, suggesting that they may be pathognomonic, the lack of familiarity with this disease prevents an early ophthalmological diagnosis. The treatment for this disorder is surgical and there is currently no known therapy for preventing or slowing the formation of cataracts; however, accurate diagnosis of this disorder may prevent inappropriate phlebotomy treatments leading to iron deficiency anemia.

8. Levi S, Girelli D, Perrone F, et al. Analysis of ferritins in lymphoblastoid cell lines and in the lens of subjects with hereditary hyperferritinemia-cataract syndrome. Blood 1998;91:4180-7.

9. Allerson CR, Cazzola M, Rouault TA. Clinical severity and thermodynamic effects of iron responsive element mutations in hereditary hyperferritinemia-cataract syndrome. J Biol Chem 1999;274:26439-47.

10. Cicilano M, Zecchina G, Roetto A, et al. Recurrent mutations in the iron regulatory element of the L-ferritin in hereditary hyperferritinemia-cataract syndrome. Haematologica 1999;84:489-92.

11. Hetet G, Devaux I, Soufir N, Grandchamp B, Beaumont C. Molecular analyses of patients with hyperferritinemia and normal serum iron values reveal both $L$ ferritin IRE and 3 new ferroportin (slc11A3) mutations. Blood 2003;102:1904-10.

12. Martin ME, Fargion S, Brissot P, Pellat B, Beaumont C. A point mutation in the bulge of the iron responsive element of the $\mathrm{L}$ - ferritin gene in two families with the hereditary hyperferritinemia-cataract syndrome. Blood 1998;91:319-23.

13. Girelli D, Bozzinic C, Zecchina G, et al. Clinical, biochemical and molecular findings in a series of families with hereditary hyperferritinemia-cataract syndrome. Br J Haematol 2001;115:334-40. 


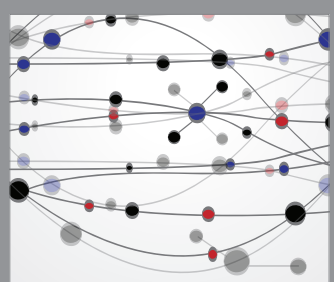

The Scientific World Journal
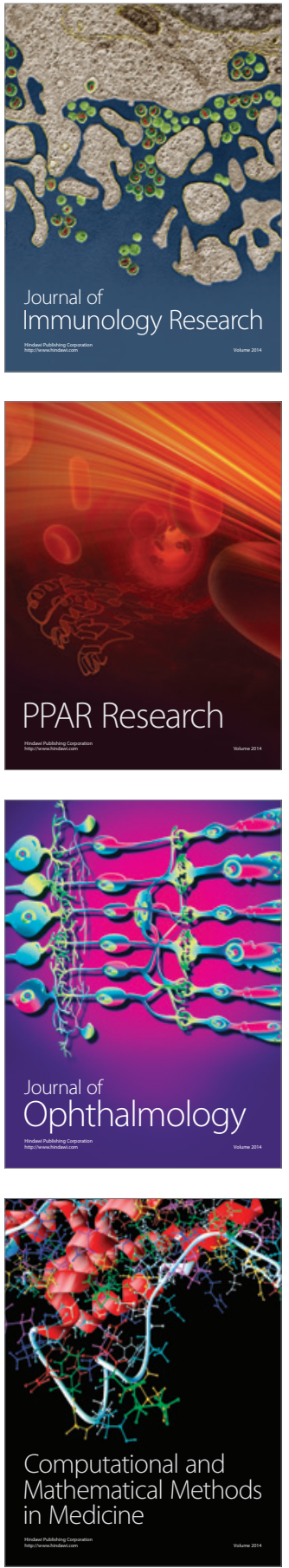

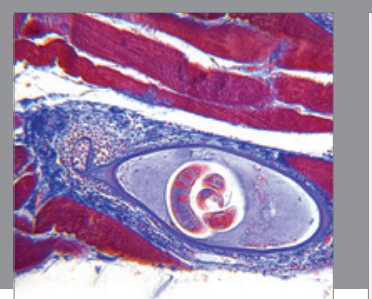

Gastroenterology Research and Practice

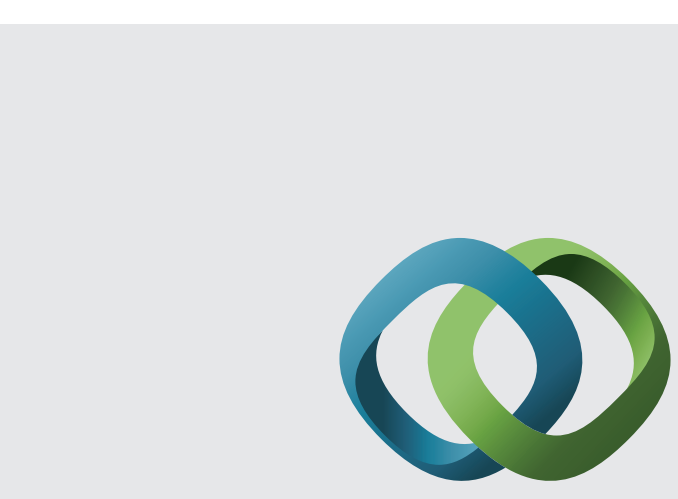

\section{Hindawi}

Submit your manuscripts at

http://www.hindawi.com
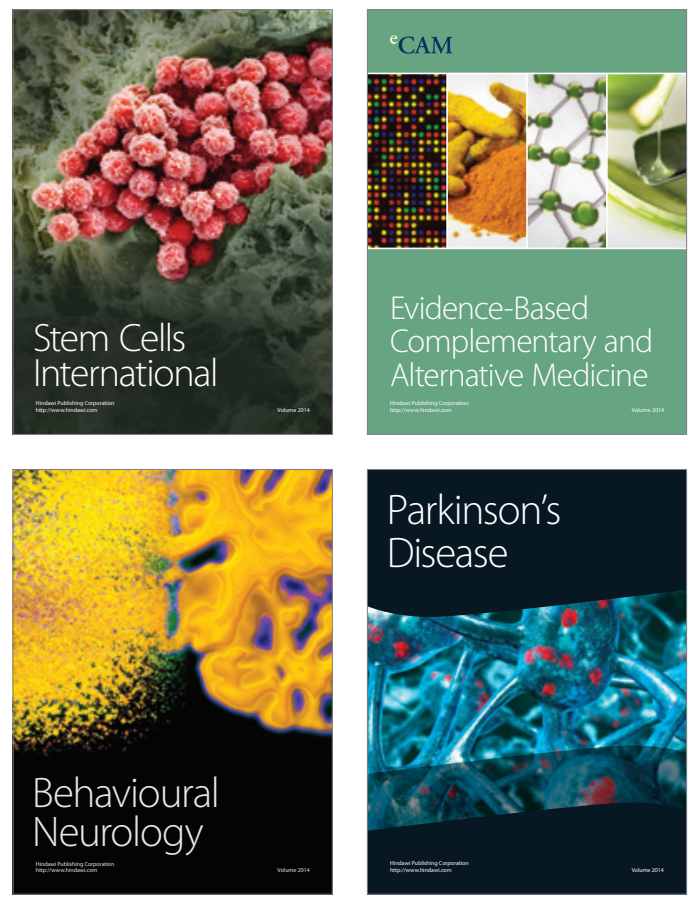
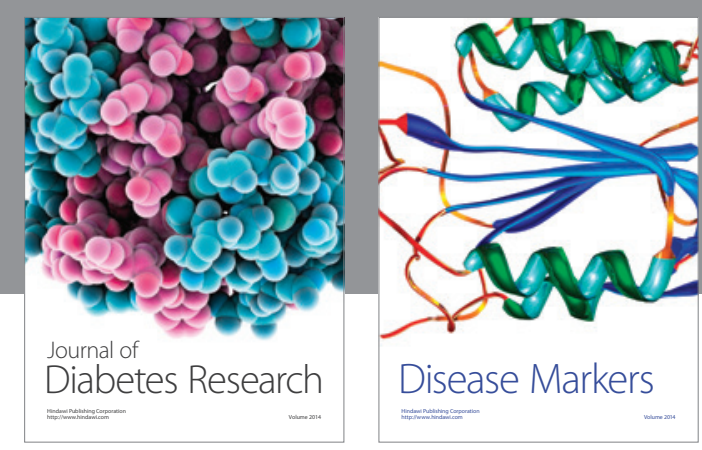

Disease Markers
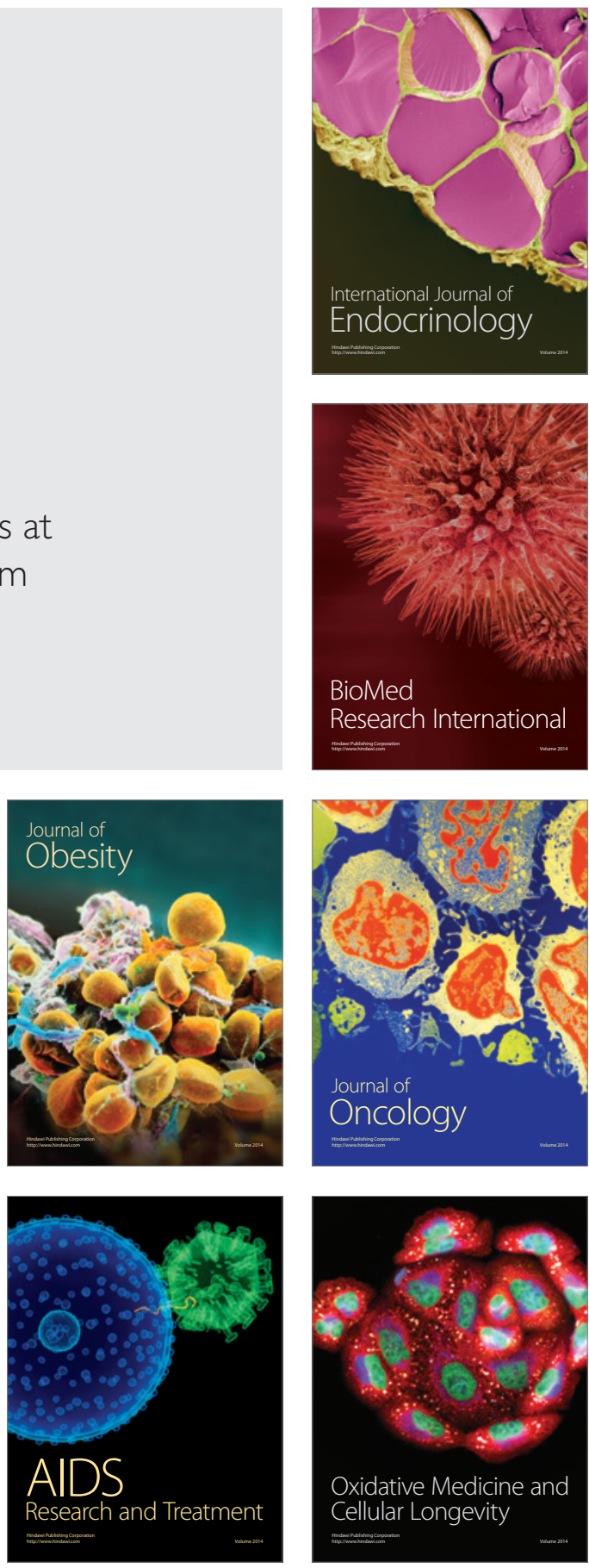